\title{
A STUDY ON E-LEARNING PREFERENCE OF TURKISH UNIVERSITY STUDENTS
}

\author{
*E. Sevinç ÇAĞLAR \\ **Tülay TURGUT \\ Beykent University, Turkey \\ MarmaraUniversity, Turkey
}

\begin{abstract}
Information and communications technology has become an important tool in education besides communicating. The use of online e-learning by members of educational communities is increasing, and this seems to be an accelerating tendency that will go on for the coming years. So it is important to identify and address students' preferences or their anxieties in e-learning, to offer beneficial programs. Although Turkish educational system is also moving parallel to this global trend, especially universities, there is only limited research on the subject. Present study aims to fill the gap with this respect, and test the effects of computer literacy, self-regulation, individualism/collectivism as personality traits to identify their contributions on e-learning preferences of university students. The sample of the study consist 606 university students from both government and private institutions which enables group comparisons. Results indicate remarkable connection between computer literacy and students' preference towards e-learning. Other variables influencing preference for e-learning are individualism/collectivism, age, grade (the year at the university), and government or private university. However, self-regulation is found to be unrelated; meaning that behavioral control has no significant contribution to e-learning preference. Based on the findings, suggestions were presented.
\end{abstract}

Keywords: e-learning, computer literacy, self-regulation, individualism/collectivism.

\section{LITERATURE REVIEW}

\section{E-learning Preference}

In the last century, the stunning development of information technologies has certainly changed the way we acquire knowledge. Networking and Internet usage has become an important tool in education besides communicating. Learning is no longer the same as before that limited to lessons in the classroom

This facility commonly called 'e-learning', can be defined as the use of telecommunication technology to deliver information for education and training (Aixia and Wang, 2011). A number of other terms are also used to describe this mode of teaching and learning. They include online learning, virtual learning, distributed learning, network and webbased learning. Fundamentally, they all refer to educational processes that utilize information and communications technology. As Naidu (2006) suggests, however, these labels refer to slightly different educational processes and they cannot be used synonymously with the term e-learning. The term e-learning comprises a lot more than online learning, virtual learning, distributed learning, networked or web-based learning. As the letter "e" in elearning stands for the word "electronic", e-learning would incorporate all educational activities that are carried out by individuals or groups working online or offline, and synchronously or asynchronously via networked or standalone computers and other electronic devices (Naidu, 2006).

During recent years, e-learning culture is seen as essential to the future of education and the facilitation of life-long learning. By enabling learners to learn anytime and anywhere, interest in it has been growing not only for companies to train their employees but also for academic institutions to establish web-course learning systems. Flexible access refers to access and use of information and resources at a time, place and pace that is suitable and convenient to individual learners rather than the teacher and/or the educational organization. It allows distance learners, to be in full or part-time employment and also be able to study at a time, place, and pace that suited their convenience. They 
would not be required to live or attend lectures in locations away from where they may be living and working.

Information and communications technology also enables the capture and storage of information of various types including print, audio, and video. It affords a wide range of opportunities to capture, store and distribute information and resources of all types and formats. Along with text, pictures and illustrations, these include multimedia-based simulations of complex processes from all sorts of domains such as the biological and medical sciences, agriculture, engineering and educational practice which are not easily or cheaply accessible in real time and settings. It ensures the increasing access to information, as well decreasing cost. Moreover; educational organizations see advantages in making their programs accessible via a range of distributed locations, including oncampus, home and other community learning or resource centers.

E-learning as an emerging new paradigm of modern education, is not without limitations or constraints. Lack of access to the necessary technology infrastructure may be counted in the first instance. Without it there can be no e-learning. Careful selection and matching of media attributes with learning and teaching strategies is another critical issue (Naidu, 2006). Academicians, educationists, and teachers should work together; and also familiarize themselves to benefit from it in the most efficient manner. But above all, an introduction of a new educational system must be assessed first place, in the light of students' characteristics (Bertea, 2009; Lee, 2004). Literature indicates many cases in which students stop their online learning after their initial experience (Aixia and Wang, 2011). The lack of human interaction conceives a socially isolated environment in which the students need to apply self-disciplined schedule and strategies. What are the attributes needed to benefit most from this type of learning? What kind of factors will be influential on students' positive approach for such systems?

As existing research indicates; positive perceptions of technology, ease of access and use of internet, computer literacy, perceived usefulness, self-efficacy, motivation, patience, self-discipline, selfregulation are among factors affecting students' attitudes toward e-learning and achievement on these programs (Bertea, 2009; Drennan, et al., 2005; Liaw et al., 2007; Nogueira and Machado, 2008; Sharma et al., 2007; Sun et al., 2008). Furthermore, some studies state the effect of national culture for e-learning preference, usability, and satisfaction (Downey, et al., 2004; McFeeters, 2003; Sánchez-Franco et al., 2009). However; there is still minimal research with respect to these issues (Sharma et al., 2007).

Turkish educational system; at all levels of education, is also moving to a trend that supports the use of information technologies. Especially universities, whether government or private, are switching rapidly to technology based systems in parallel with the worldwide undulation. There are already several instances of distant learning programs or classes held on the internet. These facilities are seemed to accelerate with an incredible speed the years ahead.

\section{Computer Literacy}

Computer literacy is the human competency to use one's own knowledge, skills and abilities from the close sphere of the hardware and software computer equipment, as well as from the wider sphere of ICT-information and communication technologies, for the collection, storage, processing, verification, evaluation, selection, distribution and presentation of information in a required form and quality to achieve their relevancy to a specified destination (Kvasnica and Hrmo, 2010).

Literature indicates confusing results in terms of computer literacy and e-learning preference interaction. Some studies present a strong relation among them not only for academic learning but also in work related activities (Folorunso et al., 2006; Paris, 2004; Sun et al., 2008). It is suggested that educators identify and address individuals' anxieties due to lack of computer literacy can be kept to a minimum while at the same time allowing learning to progress and be cultivated in a positive manner (Paris, 2004; Kvasnica and Hrmo, 2010). A study on first year medical students puts forth that; while the great majority of students possess sufficient computer skills and acknowledge the advantages of 
interactive and multimedia-enhanced learning material, a small percentage lacks basic computer skills and/or is very skeptical about e-learning (Link and Marz, 2006).

There is still some research suggesting that despite learners' adequate computer competence and having appropriate infrastructure in place, they were unwilling to take online modules. That students were still more comfortable with the traditional mode of learning where the educator is the expert and they are not completely confident on their own learning as they indicate "still need some instructions from instructors rather than control my own learning process" (Eugenia, 2007). These findings designate that there might be other variables interfere with e-learning preference. Evidently, more research needed to examine the issue.

\section{Self-regulation}

Simply put, self-regulation involves the ways in which people control and direct their own actions. One of the most important functions of self-regulation is that it provides us with the capacity to forgo the immediate gratification of small rewards to later attain larger rewards [22]. Research indicates people who learn how to delay gratification early in childhood are better adjusted later in life, both academically and socially than low self-regulators (Oyserman et al., 2004; Shoda et al., 1990).

Kanfer (1970a; 1970b; 1971) provided the first comprehensive theoretical explanation concerning self-regulation, which involved three stages, consisting of self-monitoring, self-evaluation, and selfreinforcement. The process of self-regulation involves monitoring information about one's current state and comparing it with the desired goal. Miller and Brown (1991) expanded the framework of Kanfer's model and theorized that self-regulation contains seven dimensions: 1.Receiving relevant information 2.Evaluating the information and comparing it to norms 3.Triggering change 4.Searching for options 5.Formulating a plan 6.Implementing the plan 7.Assessing the plan's effectiveness (which recycles to steps 1 and 2). Although this model was developed specifically to study addictive behaviors, the self-regulatory processes it describes are meant to be general principles of behavioral self-control (Brown et al., 1999; Carey, et al., 2004). The primary adjustment to selfregulation theory made by Miller and Brown involves articulating individual-difference factors (i.e., motivation and commitment) to reach the desired behavioral change or goal (Hustad et al., 2009).

With regard to learning; social cognitive theory (Bandura, 1986) has provided a theoretical basis for the development of a model in which personal, contextual and behavioral factors interact in such a way as to give students an opportunity to control their learning. Within this framework, Pintrich describes self-regulated learning as an active, constructive process whereby learners set goals for their learning, plan actions and monitor, regulate and control their cognition, motivation and behavior (Mousoulides and Philippou, 2005). From this perspective; self-regulated learning theory (SRL) implies that learners must possess certain self-regulatory attributes to succeed in their learning environment. These attributes suggested mainly reflect meta-cognitive strategies and abilities. Although e-learning environments may differ from traditional learning environments, for computer-based learning environments to be effective, learners must be self-regulated (Lee, 2004).

Research has identified numerous self-regulatory attributes in the frame of SRL theory, as potential contributors to performance. Many researchers have identified the importance of self-regulation as a predictor of academic success in both traditional classrooms and e-learning (Miltiadou and Savenye, 2003; Sharma et al., 2007; Zimmerman, 1986; Zimmerman and Martinez, 1986). Self-regulation has been found to be positively correlated to achievement, with highly self-regulated students being more motivated to use planning, organizational, and self-monitoring strategies than low self-regulated students (Pintrich and De Groot, 1990). With regard to e-learning, it is suggested that in order to be successful learners, e-learners must rely on their individual abilities to direct their learning, that is, employ SRL strategies (Sharma et al., 2007). All of these self-regulatory attributes selected for investigation and many more presented in existing literature, reflect the framework of SRL model. In the present study, however, self-regulation is analyzed as behavioral control mechanism, through the scope of Miller and Brown's model. 


\section{Individualism/Collectivism as Personality Traits:}

In conceptualization and measurement of individualism-collectivism dimension on the individual level; Triandis' work to develop the concept of subjective culture, was a big contribution (Wasti and Erdil, 2007). Triandis and colleagues have labeled individualism and collectivism at an individual level as idiocentrism and allocentrism respectively. It has been found that allocentrism is correlated with perceived quantity and quality of social support, and low levels of alienation and anomie, whereas idiocentrism is correlated with an emphasis on achievement and perceived loneliness (Noordin, 2004).

As indicated in several studies, individualists emphasize on personal autonomy and self-fulfillment, personal responsibility and freedom of choice, personal success, status and competitive characteristics, distinctive personal attitudes and opinions, autonomous behavior, independence of groups, need for detachment from others, and individual autonomy and functioning according to personal choices. On the other hand collectivists are likely to value belonging to their in-group and relating one's self to the group. As collectivists give more weight to norms as determinants of their social behavior, they identify themselves as members of a group to which they belong, and thus they internalize the group's goals and values and give higher priorities to them. Collectivists are associated with a strong sense of duty to group, relatedness to others, seeking others' advice, harmony, and working with the group (Singelis et al., 1995; Triandis, 2001; Oyserman and Kemmelmeier, 2002; McFeeters, 2003; Sarkar, 2005; Sánchez-Franco et al., 2009; Shulruf et al., 2011). In the light of above findings and explanations it can be expected that individualism, rather than collectivism, will be more positively related to e-learning preference.

The aim of this study is to put forth more empirical evidence in finding answers for some of the concerns on e-learning use for university students. Computer literacy, self-regulation, individualism/collectivism as personality traits are variables tested in the research, to identify their contributions on e-learning preferences of university students. The study will also enable us to compare students from Turkish private and state universities, with respect to their e-learning preferences. Their major difference is in economic terms, and these students mainly represent different socio-economic groups. So, the comparisons will be interesting in this regard. Research hypotheses and model are presented below:

Hypothesis 1: Computer literacy, self-regulation, and individualism will contribute positively on preferences of students for e-learning.

Hypothesis 2: Students from government and private universities will differentiate in terms of elearning preference.

\section{Figure 1. Research Model}

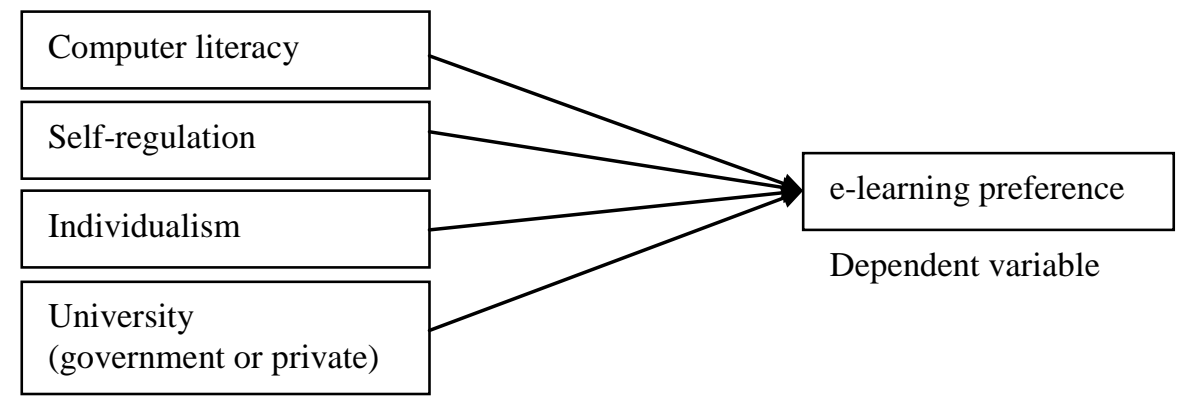

Independent variables 


\section{METHOD}

\section{Sample}

Undergraduate students $(N=606)$ from one government $(N=248)$ and one private university $(N=$ 358 ) in Istanbul took part in the study (251 male, 354 female; 1 did not report gender). The mean age is 20,72 years $(S D=2.21)$. Most of the students have computer $(88,3 \%)$ and access to internet at their home $(86,8 \%)$. The distribution of demographic variables is shown in Table 1.

\section{Table 1: Distribution of Demographic Variables}

\begin{tabular}{|c|c|c|}
\hline & Frequency & Percent \\
\hline \multicolumn{3}{|l|}{ Gender } \\
\hline Man & 251 & 41,4 \\
\hline Woman & 354 & 58,4 \\
\hline Missing & 1 & 0,2 \\
\hline Total & 606 & 100 \\
\hline \multicolumn{3}{|l|}{ University } \\
\hline Government & 248 & 59,1 \\
\hline Private & 358 & 40,9 \\
\hline Missing & 0 & 0 \\
\hline Total & 606 & 100 \\
\hline \multicolumn{3}{|l|}{ Grade } \\
\hline Freshman & 224 & 37,0 \\
\hline Sophomore & 178 & 29,4 \\
\hline Junior & 161 & 26,6 \\
\hline Senior & 40 & 6,3 \\
\hline Missing & 5 & 0,7 \\
\hline Total & 606 & 100 \\
\hline \multicolumn{3}{|c|}{ Computer at home } \\
\hline Yes & 535 & 88,3 \\
\hline No & 68 & 11,2 \\
\hline Missing & 3 & 0,5 \\
\hline Total & 606 & 100 \\
\hline \multicolumn{3}{|c|}{ Access to internet at home } \\
\hline Yes & 526 & 86,8 \\
\hline No & 66 & 10,9 \\
\hline Missing & 14 & 2,3 \\
\hline Total & 606 & 100 \\
\hline
\end{tabular}

\section{Measurement Scales:}

E-learning preference was measured with questionnaire composed of seven items. Five of the items were adapted from the scale developed by Bertea (2009) based on Mishra and Panda's (2007) scale to measure e-learning attitudes of students. These items consist e-learning issues of time management, elearning teaching efficiency, need for advanced technical abilities, schedule flexibility, reducing costs. The Cronbach's alpha of the five items was indicated as 0.749 (Bertea, 2009). The remaining two items were added by the researches. One of them directly asks whether the student would prefer elearning over classroom education, and the other asks whether they would prefer also having exams on-line. The cronbach's alpha was 0.77 for seven items.

Computer literacy, that is student's perceived comfort/anxiety with computer technologies, was measured with 15 items taken from Jones and Clarke's (1994) Computer Attitude Scale for Secondary Students (CASS). The CASS instrument was shortened since some items were out of the scope of this study, (e.g. preferences for web pages), and for practical reasons as the scale was too long (72 items). 
The Cronbach's alpha for the scale was indicated as over 0.74 in several studies (Jones and Clarke, 1994; Paris, 2004; Smalley et al., 2001) and obtained as 0.74 for 15 items on the present sample.

Self-regulation Questionnaire (SRQ) developed by Brown and her colleagues (1999) was used to measure students' self-regulation proneness. The original scale contains 63 items measuring seven sub-categories mentioned in Miller and Brown's (1991) model. Test-retest reliability and internal consistency of the SRQ are both reported as quite high $(r=.94, p<.0001$; alpha $=.91)$ (Brown et al., 1999). For practical reasons, 28 items (i.e. four items for each sub-categories) were selected for this study through attentive analyses and evaluations. The Cronbach's alpha was obtained as 0.77 for 28 items.

Turkish translation of the above three questionnaires items was held in two steps. Items were first translated into Turkish by the researchers and afterwards re-translated into English by a colleague who is capable of both languages. There found no difference in regard of meaning between original and retranslated items.

Individualism/Collectivism was measured by Turkish version of Singelis and his colleagues' (1995) INDCOL scale which is designed to measure individualism and collectivism at the individual level (Wasti and Erdil, 2007). The Cronbach's alpha levels indicated as over 0.70, which is an acceptable level (Wasti and Erdil, 2007). Out of 37 items from the original scale, 17 items were selected that fits to the purpose of the present study, and the Cronbach's alphas were .74 for collectivism and 0,71 for individualism.

All items were rated on a 6 -point scale, where $1=$ totally disagree and $6=$ totally agree. Besides of the scales indicated above; attendants' demographic information (i.e. age, sex, university, faculty, year, perceived economic status, whether they have computer and internet access at home) was collected.

\section{Procedure}

All participants were recruited during class. Their course instructors distributed the questionnaires to the students, invited them to participate on a voluntary basis, and asked them to complete the questionnaire at class time. It was emphasized that the participants should not write their names or any identifying marks on the questionnaire.

\section{RESULTS}

Descriptive statistics, Cronbach's alphas and correlations among research variables are presented in Table 2. Alpha coefficients range between .71 and .77 ; thus, all exceed the .70 minimum standard. Individualism appeared to have the highest mean value $(\mathrm{m}=4,44)$ and e-learning preference has the lowest $(\mathrm{m}=2,98)$. The correlations provide preliminary support for the first hypothesis, with elearning preference being significantly related to computer literacy $(r=.27, p<.001)$, collectivism ( $r$ $=.12, \mathrm{p}<.01)$ and individualism $(\mathrm{r}=.18, \mathrm{p}<.001)$. Age is also significantly correlated with e-learning preference $(\mathrm{r}=.21, \mathrm{p}<.001)$. However, contrary to expectation, self-regulation emerged as being unrelated to e-learning preference $(r=-.01, p>.05)$. Furthermore, correlations are significant for collectivism with individualism $(\mathrm{r}=12, \mathrm{p}<.01)$ and self-regulation $(\mathrm{r}=.22, \mathrm{p}<.001)$; individualism with self-regulation $(\mathrm{r}=.38, \mathrm{p}<.001)$. 
Table 2. Means, standard deviations, Cronbach's alpha and correlations among the variables

\begin{tabular}{lllllllll}
\hline & $\mathbf{M}$ & sd & alpha & $\mathbf{2}$ & $\mathbf{3}$ & $\mathbf{4}$ & $\mathbf{5}$ & $\mathbf{6}$ \\
\hline 1.age & 20.72 & 2.21 & & .21 & .06 & -.06 & .05 & -.05 \\
2.e-learning & 2.98 & 0.98 & .76 & & .27 & .12 & .18 & -.01 \\
3.computer lit. & 4.19 & 0.66 & .74 & & & .05 & .20 & .22 \\
4.collectivism & 3.85 & 0.75 & .74 & & & & .12 & .22 \\
5.individualism & 4.44 & 0.77 & .71 & & & & & .38 \\
6.self-regulation & 4.30 & 0.51 & .77 & & & & & \\
\hline
\end{tabular}

In order to test hypothesis 1 , multiple regression analysis by entry method was used to predict elearning preference scores from computer literacy, collectivism and individualism. Age was also entered to the model due to its significant correlation with e-learning preference, but self-regulation was not included in the regression because of its insignificant correlation. Results indicated that all four variables could predict e-learning preference significantly and accounted for $14 \%$ of the total variance (see Table 3). Of the independent variables computer literacy appeared to have the highest unique contribution to e-learning preference (standardized beta $=.23 ; \mathrm{p}<.001$ ). Analysis also revealed that age (standardized beta=.20; $\mathrm{p}<.001$ ), individualism (standardized beta=.11; $\mathrm{p}<.001$ ) and collectivism (standardized beta $=.11 ; \mathrm{p}<.01$ ) are positive predictors of e-learning preference. Thus, the results of the regression analysis partially supported hypothesis 1 .

Table 3. Regression Analysis to predict e-learning preference.

\begin{tabular}{|c|c|c|c|c|c|c|}
\hline \multicolumn{7}{|c|}{ Dependent Variable : "e-learning preference" } \\
\hline $\mathbf{R}$ & $\mathbf{R}^{2}$ & Adjusted $\mathbf{R}^{2}$ & $\mathbf{F}$ & Independent Variables & $\beta$ & $\mathbf{T}$ \\
\hline \multirow[t]{4}{*}{.37} & .14 & .13 & $23.144 * * *$ & Age & .20 & $5.27 * * *$ \\
\hline & & & & Computer Literacy & .23 & $5.83 * * *$ \\
\hline & & & & Collectivism & .11 & $2.73 * *$ \\
\hline & & & & Individualism & .11 & $2.79 * *$ \\
\hline
\end{tabular}

$* * \mathrm{p}<.01 ; * * * \mathrm{p}<.001$

Independent sample t-test was used to assess whether there is significant difference between private and government university students on e-learning preference. As shown in Table 4, a significant mean difference between private and government universities was observed $(\mathrm{t}=4,180, \mathrm{p}<.001)$; that is private university students scored significantly higher on e-learning preference. Hence, hypothesis 2 was supported.

\section{Tablo 4: e-learning preference scores of private and government university} students

\begin{tabular}{|c|c|c|c|c|c|c|}
\hline & \multicolumn{4}{|c|}{ University } & \multirow[b]{3}{*}{$\mathbf{t}$} & \multirow[b]{3}{*}{ df } \\
\hline & \multicolumn{2}{|c|}{ Private } & \multicolumn{2}{|c|}{ Government } & & \\
\hline & $\mathbf{M}$ & sd & $\mathbf{M}$ & sd & & \\
\hline e-learning preference & 3,12 & 0,94 & 2,78 & 1,01 & $4,180 * * *$ & 604 \\
\hline
\end{tabular}

$* * * \mathrm{p}<.001$

The finding related with age as being significant predictor of e-learning preference prompted the question whether there is difference in preferences among students in terms of their grade. Hence oneway Anova which was carried out to compare student groups indicated significant difference in e- 
learning preference scores $(\mathrm{F}=15,109, \mathrm{p}<.001$; see Table 5). Accordingly, freshman is lower in elearning preference scores compared to the other three student groups. Moreover, as can be seen from mean values, e-learning preference increases as the student's grade moves up. Thus this result is in line with the regression result implies that students as having more years at the university are more becoming in favor of e-learning.

Table 5. Students' grade and e-learning preference scores

\begin{tabular}{|c|c|c|c|c|c|c|c|c|c|}
\hline & \multicolumn{2}{|c|}{$\begin{array}{l}\text { Freshman } \\
\mathrm{N}=224\end{array}$} & \multicolumn{2}{|c|}{$\begin{array}{l}\text { Sophomore } \\
\mathrm{N}=178\end{array}$} & \multicolumn{2}{|c|}{$\begin{array}{l}\text { Junior } \\
\mathrm{N}=160\end{array}$} & \multicolumn{2}{|l|}{$\begin{array}{l}\text { Senior } \\
\mathrm{N}=40\end{array}$} & \\
\hline -learning & $\begin{array}{l}M \\
2.67 \mathbf{a}\end{array}$ & $\begin{array}{l}\text { sd } \\
0.97\end{array}$ & $\begin{array}{l}\mathrm{M} \\
3.06 \mathrm{~b}\end{array}$ & $\begin{array}{l}\text { sd } \\
0.97\end{array}$ & $\begin{array}{l}\text { M } \\
3.19 \mathbf{b}\end{array}$ & $\begin{array}{l}\mathrm{sd} \\
0.85\end{array}$ & $\begin{array}{l}\mathrm{M} \\
3.51 \mathbf{b}\end{array}$ & $\begin{array}{l}\mathrm{sd} \\
1.03\end{array}$ & $\begin{array}{l}\mathrm{F} \\
15.109 * * *\end{array}$ \\
\hline
\end{tabular}

$* * * \mathrm{p}<0.001$

Independent sample t-test which was also applied to compare male and female students' e-learning preference scores revealed that they are not significantly different.

\section{DISCUSSION}

The main purpose of this research was to analyze students' preferences towards e-learning and to determine some factors that have an influence on it. We include in our analysis four aspects: computer literacy, self-regulation, individualism/collectivism and demographic characteristics.

Results revealed that there is a remarkable connection between computer literacy and students' preference towards e-learning. As their technical abilities and familiarity in using computers increase, their preference to have classes on the internet is also scale up. This result is supportive to available research findings indicated in literature (Folorunso et al., 2006; Paris, 2004; Sun et al., 2008). If universities wish e-learning to include in programs they offer; extending the curriculum of courses increasing students' computer literacy will be beneficial.

Other variables influencing preference for e-learning are individualism/collectivism, age, grade (the year at the university), and government or private university. However, self-regulation is found to be unrelated; meaning that behavioral control has no significant contribution to e-learning preference. Based on previous findings indicated in literature a regulatory process at the cognitive level such that metacognitive capacities, will be more indicative of preferring e-learning (Miltiadou and Savenye, 2003; Sharma et al., 2007; Zimmerman, 1986; Zimmerman and Martinez Pons, 1986).

In terms of individualism/collectivism; individualism, compared to collectivism, was expected to make higher contribution on e-learning preference. Although, as a personality trait, it has noticeable contribution on e-learning preference, the effect rate of individualism and collectivism come out equal. For there is not much research available in the literature on this subject, it is recommended further analyses, perhaps with other instruments as well which will bring out illuminating results.

With respect to age and grade; as the students get older and reach higher grade, they prefer e-learning more. One reason for that maybe, the first year students need more social support, as they are new at the university environment. But as they get used to the system in years, they need less for such a faceto-face interaction and socialization. Also, Turkish youth undergo a process very difficult to enter the university that when they gain the entrance they most likely want to experience what a university is in real, rather than to see what it is in virtual. A limitation of this result is that the number of students from $4^{\text {th }}$ year is much fewer than the first year attendants that it might not be accurate to compare their preference levels. However, most of the $4^{\text {th }}$ year students start to work at part time jobs and it becomes somewhat difficult for them to attend classes at the university regularly. Hence, double career status might explain why $4^{\text {th }}$ year students prefer e-learning more. 
One last remark maybe on the government and private institution registered students' preference difference. The comparison test displayed that private university students are more willing to elearning. Actually, there might be numerous reasons for such a difference. But comes to mind is that private universities are much better in terms of economic conditions and advanced technologies. On the other hand, especially in Istanbul, private universities established in the city are built on a narrow field which restricts the students' alternate socialization areas (i.e. space for a range of different clubs). Thus, students at private university able to reach technology but not enough space for alternate activities might more likely prefer e-learning. Additionally, there is difference in terms of economic status between government and private university students. In our sample, 43 percent of private university students and only $23 \%$ of government university students reported that they have enough money to spend easily. Thus, most of the students at private universities belong to high socioeconomic class families and for them it is not an issue possessing advanced technology personally which facilitates e-learning.

This study which revealed some indications is thought as a preliminary study to display e-learning preference levels of university students and to examine some variables which might be in relation to elearning preference. Further studies are needed to extend the limits of knowledge on e-learning preferences.

\section{LIMITATIONS AND SUGGESTIONS FOR FURTHER STUDIES}

This study which revealed some indications is thought as a preliminary study to display e-learning preference levels of university students and to examine some variables which might be in relation to elearning preference. Although it represents an effort to identify variables that will have an impact contribution on students' preferences for e-learning, it has some limitations.

First of all; universities participated in the study are located in Istanbul. Data from other universities in various parts of the country can help to extend our perspective. Secondly; with respect to group comparisons, including more students studying in different departments, and graduate students as well, would be enlightening. Indeed, identifying students who already had an experience with elearning and ones that have never used it could make any differentiation more meaningful. Thirdly; incorporation of quantitative and qualitative research, without doubt, add value to the studies. Thorough interviews with students on their e-learning preferences would bring more scope to identify important problems and evaluate the results of quantitative research. Finally; in terms of selfregulation, testing a model that has a cognitive perspective rather than behavioral would surely enlighten us more whether it has an effect or not.

Based on the findings and some of the limitations of this study mentioned above; we believe, further studies are needed to extend the limits of knowledge on e-learning preferences. 


\section{REFERENCES}

Aixia, D. \& Wang, D. (2011). Factors Influencing Learner Attitudes Toward E-learning and development of Elearning Environment Based on the Integrated E-learning Platform. International Journal of e-Education, $e$ Business, e-Management and e-Learning. Vol. 1, No.3, pp. 264-68.

Bandura, A. (1986).Social Foundations of Thought and Action: A Social Cognitive Theory. Englewood Cliffs, NJ: Prentice Hall.

Bertea, P. (2009). Measuring students' attitude towards e-learnıng: a case study.The 5th International Scientific Conference E-Learning and Software for Education.Bucharest. http://faculty.ksu.edu.sa

Brown, Janice M.; Miller, William R.; Lawendowski, Lauren A., (1999).The self-regulation questionnaire. Innovations in clinical practice: A Source Book, (Eds.VandeCreek,L\& Jackson, T. L.) Sarasota, FL, US: Professional Resource Press/Professional Resource Exchange Vol.17, pp. 281-92.

Carey, K.B.; Neal, D.J. \& Collins, S.E. (2004).A psychometric analysis of the self-regulation questionnaire.Journal of Addictive Behaviors. Vol29, No.2, pp. 253-260.

Downey, S.; Wentling,R.M.; Wentling,T. \& Wadsworth, M.(2004). The Relationship Between National Culture and the Usability of an E-Learning System. http://nathanstrenge.com

Drennan, J.; Kennedy, J. \&Pisarski, A. (2005).Factors affecting student attitudes toward flexible online learning in management education.The Journal of Educational Research.Vol.98, no.6, pp. 331-38.

Eugenia M. W. (2007). Comparing Student Teachers' Preferencesand Perceptions on E-Learning.Managing Worldwide Operations \& Communications with Information Technology Conference pg.463-68 http://www.irmainternational.org/viewtitle/33113/

Folorunso, O.; Ogunseye, O.S. \&Sharma, S. (2006).An exploratory study of thecritical factors affecting theacceptability of e-learning inNigerian universities.Journal of Information Management \&Computer Security.Vol. 14 No. 5, pp. 496-505

Hustad, J.T.;Carey, K.; Carey, M.\&Maisto, S.A. (2009).Self-Regulation, Alcohol Consumption, and Consequences in College Student Heavy Drinkers: A Simultaneous Latent Growth Analysis. Journal of Studies in Alcohol and Drugs.Vol.70, No.3, pp.373-82.

Jones, T., andClarke, V. A. (1994). A computerattitudescaleforsecondarystudents. ComputersandEducation. Vol.22, No.4, pp.315-18.

Kanfer, F.H. (1970a).Self-monitoring: Methodological limitations and clinical applications.Journal of Consulting and Clinical Psychology. Vol.35, pp.148-152.

Kanfer, F.H. (1970b).Self-regulation: Research, issues, and speculation. In: Neuringer C,Michael JL, editors. Behavior Modification in Clinical Psychology. New York: Appleton-Century-Crofts;. pp. 178-220.

Kanfer, F.H. (1971).The maintenance of behavior by self-generated stimuli and reinforcement. In: Jacobs A, Sachs LB, editors. The Psychology of Private Events: Perspectives on Covert Response Systems. San Diego, CA: Academic Press. pp. 39-59.

Kvasnica, O. \&Hrmo, R. (2010). Importance of computerliteracyfor e-learningeducation. Joint International IGIP-SEFI Annual Conference 2010, 19th - 22nd September 2010, Trnava, Slovakia.

Lee, I. (2004). Searchingfornewmeanings of self-regulatedlearning in elearningenvironments.http://dasan.sejong.ac.kr/ inlee/set/articles/searching_040426.pdf.

Liaw, S.S.; Huang, H.M. \& Chen, G.D. (2007). Surveying instructor and learner attitudestoward elearning.Journal of Computers and Education.Vol.49, No.4, pp.1066-80.

Link, T.M. \&Marz, R. (2006).Computerliteracyandattitudestowards e-learnngamongfirstyearmedicalstudents. BMC MedicalEducation. Vol.6, No.34, pp.537-79.

McFeeters, E.F. (2003). The Effects of Individualism Vs. Collectivism on Learner's Recall, Transfer and Attitudes Toward Collaboration and Individualized Learning. Virginia Polytechnic Institute and State University.Doctorate Dissertation.scholar.lib.vt.edu

Miller, W. R., \& Brown, J. M. (1991).Self-regulation as a conceptual basis for the preventionand treatment of addictive behaviours. In N. Heather, W. R. Miller \& J. Greeley (Eds.), Self-control and the addictive behaviours(pp. 3-79). Sydney: Maxwell MacmillanPublishing Australia.

Miltiadou, M. and Savenye, W.C. (2003). Applying Social Cognitive Constructs of Motivation toEnhance Student Success in Online Distance Education. Educational Technology Review, 11 (1). 
Mischel, W.; Cantor, N. \& Feldman, S. (1996). Principles of self-regulation: The nature of willpower and selfcontrol. In E.T. Higgins \& A. W. Kruglanski (Eds), Social psychology: Handbook of basic principles (pp. 32960). New York: Guilford Press.

Mishra, S. \& Panda, S. (2007). Development andFactor Analysis of an InstrumenttomeasureFacultyAttitudetowards e-Learning. AsianJournalof DistanceEducation. Vol 5, No 1, pp 27 33

Mousoulides, N. \&Philippou, G. (2005).Students' motivational beliefs, self-regulationstrategies and mathematics achievement.In Chick, H. L. \& Vincent, J. L. (Eds.).Proceedings of the 29th Conference of the International Group for the Psychology of Mathematics Education, Vol. 3, pp. 321-28. Melbourne: PME.

Naidu, S. (2006). E-learning: A guidebook of principles, procedures, andpractices. 2nd Edition. CommonwealthEducational Media Center forAsia, New Delhi, India.

Nogueira, J. \&Machado, C. (2008).Teams in virtualclasses: an experientialperspective. Technology, Education, and Development. http://cdn.intechopen.com/pdfs/9415/pdf

Noordin, F. (2004). Individualism-collectivism: a tale of twocountries. ProblemsandPerspectives in Management. Vol. 7, No. 2, pp.36-45.

Oyserman, D.; Coon, H. M. \&Kemmelmeier, M. (2002).Rethinking individualism and collectivism: Evaluation of theoretical assumptions and meta-analyses.Psychological Bulletin.Vol 128, No.1, pp.3-72.

Oyserman, D.; Bybee, D.; Terry, K.; \& Hart-Johnson, T. (2004). Possible selves as roadmaps.Journal of Research Personality. Vol. 38, pp.130-49.

Paris,G. P. (2004). E-Learning: A study on SecondaryStudents' Attitudestowards Online Web Assisted Learning. International EducationJournal. Vol 5, No 1, http://iej.cjb.net 98

Pintrich, P.R. \& De Groot E. (1990).Motivationaland self-regulatedlearningcomponents of classroomacademicperformance. Journal of EducationalPsychology. Vol. 82, No.1, pp. 33-50.

Sánchez-Franco, M.; Martínez-López, F. \& Martín-Velicia, F. (2009). Exploring the impact of individualism and uncertainty avoidance in Web-based electronic learning: An empirical analysis in European higher education.Journal of Computers and Education. Vol52, No.3, pp 588-98J.

Sarkar, S. (2005).Individualism - collectivism as predictors of employeeattitudestowardsunionmembership: an empiricalstudy of employees of bposector in indiasarkar - cell, 2005 - baf.cuhk.edu.hk

Sharma, S.; Dick, G.; Chin, W.W.; Land, L.L. (2007).Self-regulation and e-learning.Proceedings of the Fifteenth European Conference on Information Systems, pp. 383-94., St. Gallen University of St. Gallen, retrieved in May 16, 2012 from http://is2.lse.ac.uk/asp/aspecis/2007157.pdf

Shoda, Y.; Mischel, W. \&Peake, P.K. (1990). Predicting adolescent cognitive and self-regulatory competencies from preschool delay of gratification: Identifying diagnostic conditions.Developmental Psychology. Vol. 27, pp. 278-86.

Shulruf, B.; Hattie, J. \& Dixon, R. (2011).Intertwinement of individualist and collectivist attributes and response sets. Journal of Social, Evolutionary, and Cultural Psychology. 5(1), 51-65.

Singelis, T.M.;Triandis, H.C.; Bhawuk, D.P.S.\&Gelfand, M.J. (1995). Collectivism: A

TheoreticalandMeasurementRefinementHorizontalandVerticalDimensions of IndividualismandCollectivism. Cross-CulturalResearch. Vol. 29; pp.240. http://ccr.sagepub.com/cgi/content/abstract/29/3/240

Smalley, N.; Graff, M. \&Saunders, D. (2001). A revised omputer attitudes scale for secondary students.Education and Child Psychology. Vol.18, No3., pp.47-57.

Sun, P.; Tsai, R.J.; Finger, G.; Chen, Y. \&Yeh, D. (2008). What drives a successful e-Learning? An empirical investigation of the critical factors influencing learner satisfaction.Journal of Computers \& Education. Vol. 50, No.4, pp. 1183-1202.

Triandis, H.C. (2001).Individualism-Collectivism and Personality.Journal of Personality. Vol.69,No. 6, pp. $907-$ 24.

Wasti, A. \&Erdil, (2007). Bireycilik ve toplulukçuluk değerlerinin ölçülmesi:Benlik kurgusu ve ındcol ölçeklerinin Türkçe geçerlemesi. Yönetim Araştırmaları Dergisi. Vol. 7, No. 1-2, pp. 39-66.

Zimmerman, B.J. (1986). Becoming a Self-Regulated Learner: Which Are the Key Subprocesses?Contemporary Educational Psychology. Vol.11,No.4,pp.307-13.

Zimmerman, B.J. \&Martinez Pons, M. (1986).Development of a Structured Interview for AssessingStudent Use of Self-Regulated Learning Strategies.American Educational Research Journal.Vol.23, No.4,pp. 614-28. 